\title{
Feeding saponin-containing Yucca schidigera and Quillaja saponaria to decrease enteric methane production in dairy cows ${ }^{1}$
}

\author{
L. Holtshausen, ${ }^{*}$ A. V. Chaves, ${ }^{* 2}$ K. A. Beauchemin, ${ }^{* 3}$ S. M. McGinn, ${ }^{*}$ T. A. McAllister, ${ }^{*}$ N. E. Odongo, ${ }^{* 4}$ \\ P. R. Cheeke, $†$ and C. Benchaar \\ ${ }^{*}$ Agriculture and Agri-Food Canada, Lethbridge, Alberta, Canada T1J 4B1 \\ †Department of Animal Sciences, Oregon State University, Corvallis 97331 \\ $\ddagger$ Agriculture and Agri-Food Canada, Dairy and Swine Research and Development Centre, Sherbrooke, Quebec, Canada J1M 1 Z3
}

\section{ABSTRACT}

An experiment was conducted in vitro to determine whether the addition of saponin-containing Yucca schidigera or Quillaja saponaria reduces methane production without impairing ruminal fermentation or fiber digestion. A slightly lower dose of saponin was then fed to lactating dairy cows to evaluate effects on ruminal fermentation, methane production, total-tract nutrient digestibility, and milk production and composition. A 24-h batch culture in vitro incubation was conducted in a completely randomized design with a control (no additive, CON) and 3 doses of either saponin source [15, 30, and $45 \mathrm{~g} / \mathrm{kg}$ of substrate dry matter (DM)] using buffered ruminal fluid from 3 dairy cows. The in vivo study was conducted as a crossover design with 2 groups of cows, 3 treatments, and three 28-d periods. Six ruminally cannulated cows were used in group 1 and 6 intact cows in group $2(627 \pm 55 \mathrm{~kg}$ of body weight and $155 \pm 28 \mathrm{~d}$ in milk). The treatments were 1 ) early lactation total mixed ration, no additive (control; CON); 2) CON diet supplemented with whole-plant $Y$. schidigera powder at $10 \mathrm{~g} / \mathrm{kg}$ of DM (YS); and 3) CON diet supplemented with whole-plant $Q$. saponaria powder at $10 \mathrm{~g} / \mathrm{kg}$ of DM (QS). Methane production was measured in environmental chambers and with the sulfur hexafluoride $\left(\mathrm{SF}_{6}\right)$ tracer technique. In vitro, increasing levels of both saponin sources decreased methane concentration in the headspace and increased the proportion of propionate in the buffered rumen fluid. Concentration of ammonia- $\mathrm{N}$, acetate proportion, and the acetate:propionate ratio in the buffered rumen fluid as well as 24-h digestible neutral detergent fiber were

Received October 27, 2008

Accepted February 10, 2009.

${ }^{1}$ This is a corrected article. The original article omitted author N. E. Odongo.

${ }^{2}$ Current address: University of Sydney, Faculty of Veterinary Science, Sydney, NSW 2006, Australia.

${ }^{3}$ Corresponding author: Karen.beauchemin@agr.gc.ca

${ }^{4}$ Current address: International Atomic Energy Agency, Department of Nuclear Sciences and Applications, PO Box 100, Wagramer Strasse 5, A-1400, Vienna, Austria. reduced compared with the CON treatment. Medium and high saponin levels decreased DM digestibility compared with the CON treatment. A lower feeding rate of both saponin sources $(10 \mathrm{~g} / \mathrm{kg}$ of $\mathrm{DM})$ was used in vivo in an attempt to avoid potentially negative effects of higher saponin levels on feed digestibility. Feeding saponin did not affect milk production, total-tract nutrient digestibility, rumen fermentation, or methane production. However, DM intake was greater for cows fed YS and QS than for CON cows, with a tendency for greater DM intake for cows fed YS compared with those fed QS. Consequently, efficiency of milk production ( $\mathrm{kg}$ of milk/ $\mathrm{kg}$ of DM intake) was lower for cows fed saponin compared with controls. The results show that although saponin from $Y$. schidigera and $Q$. saponaria lowered methane production in vitro, the reduction was largely due to reduced ruminal fermentation and feed digestion. Feeding a lower dose of saponin to lactating dairy cows avoided potentially negative effects on ruminal fermentation and feed digestion, but methane production was not reduced. Lower efficiency of milk production of cows fed saponin, and potential reductions in feed digestion at high supplementation rates may make saponin supplements an unattractive option for lowering methane production in vivo.

Key words: Yucca schidigera, Quillaja saponaria, methane, rumen fermentation

\section{INTRODUCTION}

Plant extracts containing saponin are of interest as potential feed additives for dairy and beef cattle because they inhibit rumen ciliate protozoa (Wallace et al., 1994; Cheeke, 2000; Teferedegne, 2000; Benchaar et al., 2007). Defaunation often lowers rumen methanogenesis (Hess et al., 2003a, 2004; Santoso et al., 2004) because about $25 \%$ of ruminal methanogens live in association with protozoa (Newbold et al., 1997). Reducing methanogenesis is beneficial from the standpoint of increasing energy efficiency of the cow (Johnson and Johnson, 1995) and from an environmental perspective because 
methane is a potent greenhouse gas (Intergovernmental Panel on Climate Change, 2007).

The 2 major commercial sources of saponin are from desert plants: Yucca schidigera from Mexico and Quillaja saponaria from Chile. Yucca saponins have a steroidal nucleus, whereas Quillaja saponins are triterpenoids. A recent in vitro study (Pen et al., 2006) showed that liquid extracts of $Y$. schidigera and $Q$. saponaria added at 2 to $6 \mathrm{~mL} / \mathrm{L}$ of buffered ruminal fluid decrease rumen protozoa and have the potential to alter ammonia-N and propionate concentrations, and acetate:propionate ratio. In the same study, $Y$. schidigera reduced rate and extent of methane production in a dose-dependent manner by up to 42 and $32 \%$, respectively, whereas $Q$. saponaria did not affect methane production.

Methane production in ruminants is negatively correlated with energy utilization; thus, reduction of methane production through the use of feed additives and rechanneling hydrogen to short-chain fatty acids and microbial mass (Lila et al., 2003) is desirable, provided that the additives do not adversely affect animal productivity. The objectives of our study were to determine 1) in vitro the ruminal fermentation and methane production responses to increasing doses of saponin from $Y$. schidigera and Q. saponaria, and 2) the effects of feeding these saponin sources on ruminal fermentation, methane production, total-tract nutrient digestibility, and milk production and composition in dairy cows. Our hypothesis was that saponin-containing $Y$. schidigera and Q. saponaria would lower methane production and thereby improve the efficiency of milk production in dairy cows.

\section{MATERIALS AND METHODS}

Two experiments were conducted at Agriculture and Agri-Food Canada's Research Centre in Lethbridge, Alberta, Canada. The cows were cared for in accordance with the guidelines of the Canadian Council on Animal Care (1993).

\section{In Vitro Study}

An in vitro incubation was conducted in a completely randomized design using a control (no additive, CON) and 3 doses $(15,30$, and $45 \mathrm{~g} / \mathrm{kg}$ of substrate DM) of 2 saponin sources ( $Y$. schidigera and $Q$. saponaria) in a 24 -h batch culture. The $Y$. schidigera whole-plant powder contained $6.0 \%$ saponin (wt/wt) and the $Q$. saponaria whole-plant powder contained $3.0 \%$ saponin (wt/wt; both saponin sources from Desert King International, San Diego, CA). Ruminal fluid was obtained from 3 Holstein dairy cows $(617 \pm 8.9 \mathrm{~kg}$ of BW; 45 \pm 13 DIM) fed a barley silage-based TMR (16.7\% CP,
$34.4 \% \mathrm{NDF}$ ) with a 51:49 forage:concentrate ratio. A representative sample of the TMR was freeze-dried and ground through a 1-mm screen Wiley mill (standard model 4, Arthur H. Thomas, Philadelphia, PA) for use in the in vitro incubation.

A day before the incubation, $0.5 \mathrm{~g}$ (DM) of dietary substrate and 15,30 , and $45 \mathrm{~g}$ of either saponin source/ $\mathrm{kg}$ of substrate DM were weighed into $50-\mathrm{mL}$ glass incubation bottles ( $\mathrm{n}=6$ per treatment). On the day of incubation, the bottles containing the samples were prewarmed to $39^{\circ} \mathrm{C}$ in an incubator for $60 \mathrm{~min}$. The incubation was initiated by adding $20 \mathrm{~mL}$ of inoculum to each bottle. For the inoculum, ruminal contents were obtained $2 \mathrm{~h}$ after the morning feeding from different sites within the rumen and pooled across the 3 cows. The composite rumen sample was strained through 4 layers of cheesecloth into an insulated thermos and immediately transported to the laboratory. The strained ruminal fluid was maintained at $39^{\circ} \mathrm{C}$ in a water bath and the headspace continuously flushed with $\mathrm{CO}_{2}$. The ruminal fluid was mixed with 3 volumes of prewarmed buffer at $39^{\circ} \mathrm{C}$ and $0.5 \mathrm{~mL}$ of cysteine sulfide solution as a reducing agent (Menke et al., 1979). The bottles were sealed with rubber stoppers, crimp-sealed to avoid gas leakage, and then affixed to a rotary shaker platform (90 rpm; Lab-Line Instruments Inc., Melrose Park, IL) in a temperature-controlled $\left(39 \pm 0.5^{\circ} \mathrm{C}\right.$ ) incubator (model 39419-1, Forma Scientific, Marietta, OH). Six bottles without substrate (as blanks) were also prepared for each time point.

Total gas production was measured at $0,2,6,12$, and $24 \mathrm{~h}$, whereas $\mathrm{CH}_{4}$ concentration, $\mathrm{pH}$, ammonia-N, total and individual concentrations of VFA, in vitro DM (IVDMD) and NDF (IVNDFD) digestibility were determined after $24 \mathrm{~h}$ of incubation.

Fermentation Gases. After 2, 6, and $12 \mathrm{~h}$ of incubation, bottles were removed from the incubator for measurement of gas production using a water displacement technique (Fedorak and Hrudey, 1983) and then returned to the incubator. After $24 \mathrm{~h}, 6$ replicates were used to determine gas production as above, and 3 replicates were used to determine methane concentration in the headspace gas. Approximately $20 \mathrm{~mL}$ of headspace gas was obtained from the bottles by inserting a $30-\mathrm{mL}$ syringe fitted with a 1.5 -inch 22 -gauge needle through the septum and immediately transferring the contents of the syringe into a 5.9-mL evacuated Exetainer (Labco Ltd., Buckinghamshire, United Kingdom) while ensuring positive pressure in the containers. A subsample of gas $(3 \mathrm{~mL})$ was removed from each Exetainer and analyzed for methane by GLC. Net total gas production was calculated by adding the $20 \mathrm{~mL}$ in the syringe (methane sample) to the reading of water displacement and subtracting the gas production in the blank bottles. 
Methane was expressed as milligrams of methane per gram of DM incubated, and total net gas production as milliliters per gram of DM incubated. After $24 \mathrm{~h}$ of incubation, the contents of the incubation bottles were transferred into preweighed $50-\mathrm{mL}$ centrifuge tubes, rinsed with distilled water into the tubes, and centrifuged twice at $500 \times g$ for $10 \mathrm{~min}$ at $4^{\circ} \mathrm{C}$. The supernatant was discarded, and the precipitate dried at $55^{\circ} \mathrm{C}$ for $48 \mathrm{~h}$ and weighed to estimate IVDMD. The dried precipitates were subsequently analyzed for NDF concentrations (Van Soest et al., 1991) to estimate IVNDFD.

Ammonia-N and VFA. After gas was sampled for methane and the total gas production was determined for the $24 \mathrm{~h}$ sample, the $\mathrm{pH}$ of the whole culture was measured using a pH meter (Orion Model 260A, Fisher Scientific, Toronto, Ontario, Canada) calibrated at $39^{\circ} \mathrm{C}$, and the bottles were placed on ice to terminate the fermentation. Two subsamples $(1.6 \mathrm{~mL})$ of the culture in each bottle were transferred to 2-mL microcentrifuge tubes containing $150 \mu \mathrm{L}$ of TCA $(0.65 ; \mathrm{vol} / \mathrm{vol})$ and centrifuged at $14,000 \times g$ for $10 \mathrm{~min}$ (Spectrafuse $16 \mathrm{M}$, National Labnet Co., Edison, NJ) to precipitate particulate matter. The supernatant was transferred into 2-mL microcentrifuge tubes (Fisher Scientific, Ottawa, Ontario, Canada) and frozen at $-20^{\circ} \mathrm{C}$ until analyzed for ammonia-N.

Two additional subsamples $(1.5 \mathrm{~mL})$ of the culture in each bottle were removed, acidified with $300 \mu \mathrm{L}$ of metaphosphoric acid (0.25; wt/vol), and centrifuged similar to those for ammonia- $\mathrm{N}$ analysis. The supernatant was frozen at $-20^{\circ} \mathrm{C}$ until analysis for VFA concentrations. Blank 0-h samples were also analyzed for ammonia-N and VFA to calculate net ammonia-N and net total VFA production.

\section{In Vivo Study}

Experimental Design and Treatments. The experiment was conducted as a crossover design with 2 groups of 6 cows, 3 treatments, and three 28-d periods. The first $7 \mathrm{~d}$ of each period were used to gradually transition animals to the next treatment, and the last $21 \mathrm{~d}$ were used for measurements. Twelve lactating Holstein dairy cows $(627 \pm 55 \mathrm{~kg}$ of BW and $155 \pm 28 \mathrm{DIM})$, including 6 that were ruminally cannulated (group 1) and 6 that were intact (group 2), were paired by BW (1 cannulated and 1 intact) and randomly assigned to 3 treatments within the 2 groups. The treatments were 1) early lactation TMR with a 51:49 forage:concentrate ratio (DM basis) without additive (control; CON), 2) CON diet plus $Y$. schidigera (Desert King International; YS), and 3) CON diet plus Q. saponaria (Desert King International; QS). Both saponin sources were added to the feed mixer (Data Ranger, American Calan Inc., Northwood, NH) at $10 \mathrm{~g} / \mathrm{kg}$ of DM. This level of saponin supplementation was below the lowest level used in the in vitro study, and was selected so as not to adversely affect animal performance.

Cow Management. Cows were housed in individual tie stalls fitted with rubber mattresses and bedded with wood shavings, except when they were moved to the environmental chambers for methane production measurement during the last week of each period (Monday to Friday). The CON diet was formulated using the NRC (2001) model to supply sufficient energy and N for a $650-\mathrm{kg}$ cow producing $35 \mathrm{~kg} / \mathrm{d}$ of milk containing $3.5 \%$ fat and $3.2 \%$ protein (Table 1 ). The diets were prepared fresh daily using a feed mixer (Data Ranger) and offered twice daily at 0700 and $1500 \mathrm{~h}$ for ad libitum intake ( 5 to $10 \%$ orts). The quantities of feed offered and refused by each cow were recorded daily throughout the experiment, and samples of the TMR and refusals were obtained weekly for DM content determination. Ad libitum DMI for each cow was calculated based on the first $23 \mathrm{~d}$ of each period, representing the days before the cows were moved to the environmental chambers.

Cows were milked twice daily at 0630 and $1630 \mathrm{~h}$, and milk was sampled during the a.m. and p.m. milkings on 3 consecutive days (d 17 to 19 ) in each period. Milk samples were preserved with potassium dichromate and stored at $4^{\circ} \mathrm{C}$ until sent to CanWest DHI (Central Milk Testing Laboratory, Edmonton, Alberta, Canada) for analysis of fat, CP, and lactose (AOAC, 1995) using an infrared analyzer (MilkoScan 605, Foss Electric, Hillerød, Denmark). Milk composition was corrected for differences in milk volume between a.m. and p.m. milkings. Cows were turned out daily for at least $1 \mathrm{~h}$ after the morning milking to a dry-lot for exercise. The cows were weighed at the beginning of the experiment and at the end of each period to monitor changes in BW.

Chamber Methane Measurements. On d 25 of each period, the cows were moved to 3 environmental chambers (2 cows/chamber) for methane production measurements. The periods were staggered for groups 1 and 2 because only 3 chambers were available at a time. The cows were adapted to the environmental chamber facilities and procedures before starting the experiment. The chambers measured $4.4 \mathrm{~m}$ wide $\times 3.7$ $\mathrm{m}$ deep $\times 3.9 \mathrm{~m}$ tall $\left(63.5 \mathrm{~m}^{3}\right.$ volume, C1330, Conviron Inc., Winnipeg, Manitoba, Canada). Two cows paired at the beginning of the experiment as described previously were housed in each chamber such that the total BW of cows per chamber and per treatment was similar. The pairing of animals was consistent throughout the experiment and the cows within a chamber received the same treatment. 
Table 1. Ingredients and chemical composition of the basal diet fed to dairy cows in a study to determine the effect of saponin supplementation on animal performance

\begin{tabular}{|c|c|}
\hline Item $^{1}$ & $\%$ of DM \\
\hline \multicolumn{2}{|l|}{ Ingredients } \\
\hline Barley silage $^{2}$ & 46.6 \\
\hline Alfalfa hay ${ }^{3}$ & 4.5 \\
\hline Corn, dry rolled & 12.8 \\
\hline Barley, steam rolled & 15.3 \\
\hline Canola meal, Alberta Gold ${ }^{4}$ & 4.15 \\
\hline Soybean meal & 4.13 \\
\hline Corn gluten meal & 3.41 \\
\hline Barley, ground & 2.82 \\
\hline Beet pulp & 2.38 \\
\hline Molasses, dry & 1.29 \\
\hline Canola oil & 0.84 \\
\hline Corn, ground & 0.10 \\
\hline Dicalcium phosphate & 0.54 \\
\hline Calcium carbonate & 0.35 \\
\hline Sodium bicarbonate & 0.32 \\
\hline Mineral-vitamin $\operatorname{mix}^{5}$ & 0.52 \\
\hline Flavor $^{6}$ & 0.01 \\
\hline \multicolumn{2}{|l|}{ Chemical composition } \\
\hline DM & $52.1(1.69)^{7}$ \\
\hline $\mathrm{OM}$ & $92.7(0.08)$ \\
\hline $\mathrm{CP}$ & $17.0(0.14)$ \\
\hline $\mathrm{NDF}$ & $34.7(0.26)$ \\
\hline $\mathrm{ADF}$ & $22.6(0.47)$ \\
\hline Ash & $7.2(0.08)$ \\
\hline $\mathrm{NE}_{\mathrm{L}},{ }^{8} \mathrm{Mcal} / \mathrm{kg}$ & $1.55(0.007)$ \\
\hline
\end{tabular}

${ }^{1}$ All ingredients except barley silage, alfalfa hay, dry-rolled corn, and steam-rolled barley were provided as part of a pelleted supplement.

${ }^{2}$ Composition (DM basis): $40.9 \% \mathrm{DM}, 8.4 \% \mathrm{CP}, 43.0 \% \mathrm{NDF}$, and $24.9 \%$ ADF.

${ }^{3}$ Composition (DM basis): $89.6 \% \mathrm{DM}, 14.6 \% \mathrm{CP}, 53.1 \% \mathrm{NDF}$, and $38.4 \% \mathrm{ADF}$

${ }^{4}$ Supplied by Richardson Nutrition (Winnipeg, Manitoba, Canada).

${ }^{5}$ Contained (\% mineral-vitamin mix, DM basis): $58.8 \% \mathrm{NaCl}, 16.0 \%$ Dynamate (IMC-Agrico Feed Ingredients Ltd., Oakville, Ontario, Canada; $22 \% \mathrm{~S}, 18 \% \mathrm{~K}, 11 \% \mathrm{Mg}, 5 \mathrm{mg} / \mathrm{kg} \mathrm{Pb}, 1,000 \mathrm{mg} / \mathrm{kg} \mathrm{Fe}) ; 2.4 \%$ $\mathrm{MnSO}_{4} \cdot 4 \mathrm{H}_{2} \mathrm{O}, 2.0 \% \mathrm{ZnSO}_{4} \cdot \mathrm{H}_{2} \mathrm{O}, 0.8 \% \mathrm{CuSO}_{4} \cdot 5 \mathrm{H}_{2} \mathrm{O}, 0.012 \%$ ethylenediamine dihydroiodide, $0.009 \% \mathrm{Na}_{2} \mathrm{SeO}_{3}, 0.009 \% \mathrm{CoSO}_{4} \cdot 6 \mathrm{H}_{2} \mathrm{O}$, and per kilogram of DM:, 2,000,000 IU vitamin A, 200,000 IU vitamin D, and $2,000 \mathrm{IU}$ vitamin E.

${ }^{6}$ Anise 422 powder containing ground cumin, fennel, and fenugreek, and silicon dioxide and wheat bran (Canadian Bio-Systems Inc., Calgary, Alberta, Canada).

${ }^{7}$ Standard deviation shown in parentheses.

${ }^{8}$ Estimated according to the NRC (2001).

Methane emission was measured for 3 consecutive days beginning approximately $12 \mathrm{~h}$ after the cows were put in the chambers. Methane concentrations in the intake and exhaust air ducts were monitored using a methane analyzer (model Ultramat 5E, Siemens Inc., Karlsruhe, Germany). The difference between the incoming and outgoing mass of methane was used to calculate the amount generated in each chamber by the 2 cows. Details of the calculation of methane emissions were reported by McGinn et al. (2004).

$\boldsymbol{S F}_{6}$ Methane Measurements. Methane emission was also measured on a subset of the animals (6 ruminally cannulated cows) using the sulfur hexafluoride
$\left(\mathrm{SF}_{6}\right)$ tracer technique. These measurements were made using the procedure described by McGinn et al. (2006) on 5 consecutive days while the animals were housed in the individual tie-stall barn.

Rumen Fermentation Measurements. Rumen fermentation characteristics ( $\mathrm{pH}$, ammonia-N, and VFA) and protozoal numbers were measured before starting the experiment and on d 4, 7, 14, 21, and 28 of each period. Approximately $1 \mathrm{~L}$ of rumen contents was obtained $2 \mathrm{~h}$ after feeding from multiple sites in the rumen from the 6 rumen-cannulated cows, composited by cow, and strained through a PECAP polyester screen (pore size $355 \mu \mathrm{m}$; B. \& S. H. Thompson, Ville Mont-Royal, Quebec, Canada). The pH of the filtered ruminal fluid was measured within 5 min of collecting the rumen contents using a $\mathrm{pH}$ meter (Accumet model 25, Denver Instrument Company, Arvada, CO). Five milliliters of filtrate was preserved by adding $1 \mathrm{~mL}$ of $25 \% \mathrm{HPO}_{3}$ and used to determine VFA, $5 \mathrm{~mL}$ was preserved by adding $1 \mathrm{~mL}$ of $1 \% \mathrm{H}_{2} \mathrm{SO}_{4}$ and used to determine ammonia- $\mathrm{N}$, and $5 \mathrm{~mL}$ was preserved with 5 $\mathrm{mL}$ of methyl green-formalin-saline solution $(1: 1, \mathrm{vol} /$ vol) for protozoa enumeration. Protozoa samples were stored at room temperature and protected from light until counted. Samples for VFA and ammonia-N determination were stored frozen at $-20^{\circ} \mathrm{C}$ until analysis.

Apparent Digestibility. Approximately $10.0 \pm 0.1$ $\mathrm{g}$ of marker, providing $1.87 \mathrm{~g}$ of $\mathrm{Cr}$, was top-dressed and hand-mixed onto the TMR of individual cows twice daily (a.m. and p.m. feeding) for 10 consecutive days of each period (d 12 to 21). Fecal samples (100 g of wet weight) were obtained twice daily at different times on each day (d 1: 1000, $1500 \mathrm{~h}$; d 2: 1100, $1700 \mathrm{~h}$; d 3: 0800, $1400 \mathrm{~h}$; d 4:0900, $1600 \mathrm{~h}$; d 5: 0700, $1200 \mathrm{~h}$ ) from the rectum of each cow on the last $5 \mathrm{~d}$ of marker dosing (d 17 to 21 ). The samples were pooled by period for each cow and frozen at $-20^{\circ} \mathrm{C}$ until analysis. The samples were later thawed and dried at $55^{\circ} \mathrm{C}$ for $48 \mathrm{~h}$ in a forced-draft oven, ground through a $1-\mathrm{mm}$ screen, and analyzed for Cr, DM, gross energy, CP, NDF, and ADF. Chromium was assumed to be unabsorbed and the nutrient composition of orts was taken into account when the digestibility of the DM for each day of fecal collection was calculated:

$$
\mathrm{DM} \text { digestibility }=100-\frac{\% \mathrm{Cr} \text { in Feed }}{\% \mathrm{Cr} \text { in Feces }} \times \frac{\% \mathrm{DM} \text { in Feces }}{\% \mathrm{DM} \text { in Feed }}
$$

Digestibility of gross energy, $\mathrm{CP}, \mathrm{NDF}$, and ADF were calculated using the same approach.

Laboratory Analyses. Analyses were performed on each sample in duplicate; when the coefficient of variation was $>5 \%$, the analysis was repeated. Analytical DM was determined by drying the oven-dried samples 
at $135^{\circ} \mathrm{C}$ for $2 \mathrm{~h}$, followed by hot weighing (AOAC, 1995; method 930.05). Gross energy was determined using an adiabatic calorimeter (model 1241, Parr, Moline, IL). The NDF was determined, as described by Van Soest et al. (1991), using heat-stable $\alpha$-amylase and sodium sulfite, and ADF was determined according to procedures of the AOAC (1995; method 973.18). For the measurement of $\mathrm{CP}(\mathrm{N} \times 6.25)$, samples were ground to a fine powder using a ball mill (Mixer Mill MM2000, Retsch, Haan, Germany), and N was quantified by flash combustion with gas chromatography and thermal conductivity detection (Carlo Erba Instruments, Milan, Italy). Chromium was determined by inductively coupled plasma emission spectrometry (SpectoCirosCCD, Specto Analytical Instruments GmbH, Kleve, Germany) after dry ashing and extraction with $\mathrm{H}_{3} \mathrm{PO}_{4}$, $\mathrm{MnSO}_{4}$, and $\mathrm{KBrO}_{3}$. The VFA were quantified using a gas chromatograph (model 5890, Hewlett-Packard, Palo Alto, CA $)$ with a capillary column $(30 \mathrm{~m} \times 0.32 \mathrm{~mm}$ i.d., 1- $\mu \mathrm{m}$ phase thickness, Zebron ZB-FAAP, Phenomenex, Torrance, CA), and flame-ionization detection. The oven temperature was $170^{\circ} \mathrm{C}$ held for $4 \mathrm{~min}$, which was then increased by $5^{\circ} \mathrm{C} / \mathrm{min}$ to $185^{\circ} \mathrm{C}$, and then by $3^{\circ} \mathrm{C} / \mathrm{min}$ to $220^{\circ} \mathrm{C}$, and held at this temperature for 1 min. The injector temperature was $225^{\circ} \mathrm{C}$, the detector temperature was $250^{\circ} \mathrm{C}$, and the carrier gas was helium. Ammonia-N was determined using the method described by Weatherburn (1967), modified for use with a plate reader. Ruminal protozoa were counted using a Fuchs-Rosenthal counting chamber (Hausser Scientific Partnership, Horsham, PA) as described by Ogimoto and Imai (1981).

\section{Statistical Analyses}

Data were analyzed with the mixed model procedure (SAS Institute, 2001). For the in vitro study, saponin treatment means for each level were compared against the CON using the least squares mean linear hypothesis test (LSMEANS/DIFF) with the Dunnett adjustment. Orthogonal polynomial contrasts were used to determine linear and quadratic responses to level of saponin $(0,15,30$, and $45 \mathrm{~g}$ of saponin $/ \mathrm{kg}$ of substrate $\mathrm{DM})$ within each saponin source.

In the in vivo study, individual cow was the experimental unit for all variables, except for chamber methane production, where chamber was the experimental unit. The model for DMI, nutrient digestibility, ruminal fermentation, protozoal numbers ( $\log _{10}$ transformed data), and milk variables included the fixed effects of diet and group (no group effect for fermentation or protozoal variables) and their interaction; cow within group, and period within group were considered random effects. The model used for methane production included the fixed effect of diet and the random effects of group, period within group, and chamber within group, with day of sampling within period treated as a repeated measure. The REML method was used for estimating the variance components, and degrees of freedom were adjusted using the Kenward-Roger option. The appropriate variance-covariance error structure was determined by the lowest Akaike information criterion value. Treatment mean comparisons were for preplanned contrasts: 1) CON versus YS and QS, and 2) YS versus QS. Treatment differences were declared at $P<0.05$.

\section{RESULTS AND DISCUSSION}

\section{In Vitro Study}

Supplementation with either saponin source decreased methane production, but it also generally had other undesirable effects on ruminal fermentation and feed digestion. The reduction in methane production was at least partially attributed to a decrease in feed digestibility, particularly NDF digestibility. Ammonia-N concentration, proportion of acetate, and acetate:propionate ratio were all lower $(P<0.01)$ compared with the CON treatment regardless of concentration of saponin (Table $2)$. These variables generally declined linearly $(P<$ 0.01 ) with increasing level of saponin. Total gas production, methane concentration in the headspace, IVDMD, and IVNDFD were also decreased, although for some saponin levels the decrease was only numerical. Several other authors have reported a decrease in methane production related to saponin addition in vitro (Hess et al., 2003a; Lila et al., 2003; Pen et al., 2006) and a decrease in NDF digestion (Hess et al., 2003a) or DM digestion (Lila et al., 2003). There is, however, at least one report of no effect on in vitro methane production with saponin addition (Wang et al., 1998).

Potential explanations for inconsistent results among studies include saponin source and dose level. Hess et al. (2003a) evaluated saponin from 3 different sources (Sapindus saponaria, Enterolobium cyclocarpum, Pithecellobium saman) in forage-based diets using the Rusitec system and reported a decrease in methane production only for S. saponaria. Wang et al. (1998) and Lila et al. (2003) both used Y. schidigera in mixed hay-concentrate diets. Lila et al. (2003) reported a reduction in methane production in vitro at a dose level of 1.2 to $3.2 \mathrm{~g}$ of saponin/L, whereas Wang et al. (1998) reported no effect at a much lower dose level $(0.022 \mathrm{~g}$ of saponin/L). However, in contrast to the study by Wang et al. (1998), the lowest dose level used in our study decreased methane production even though that dose $(15 \mathrm{~g}$ of $Y$. schidigera whole plant is equivalent to $0.9 \mathrm{~g}$ of saponin $/ \mathrm{kg}$ of $\mathrm{DM}=0.023 \mathrm{~g} / \mathrm{L}$, with 0.5 
Table 2. Effects of Yucca schidigera and Quillaja saponaria on in vitro cumulative gas production, methane concentration, net ammonia-N production, yield and proportions of VFA, pH, and estimates of in vitro DM digestibility (IVDMD) and in vitro NDF digestibility (IVNDFD) over a 24 -h incubation period

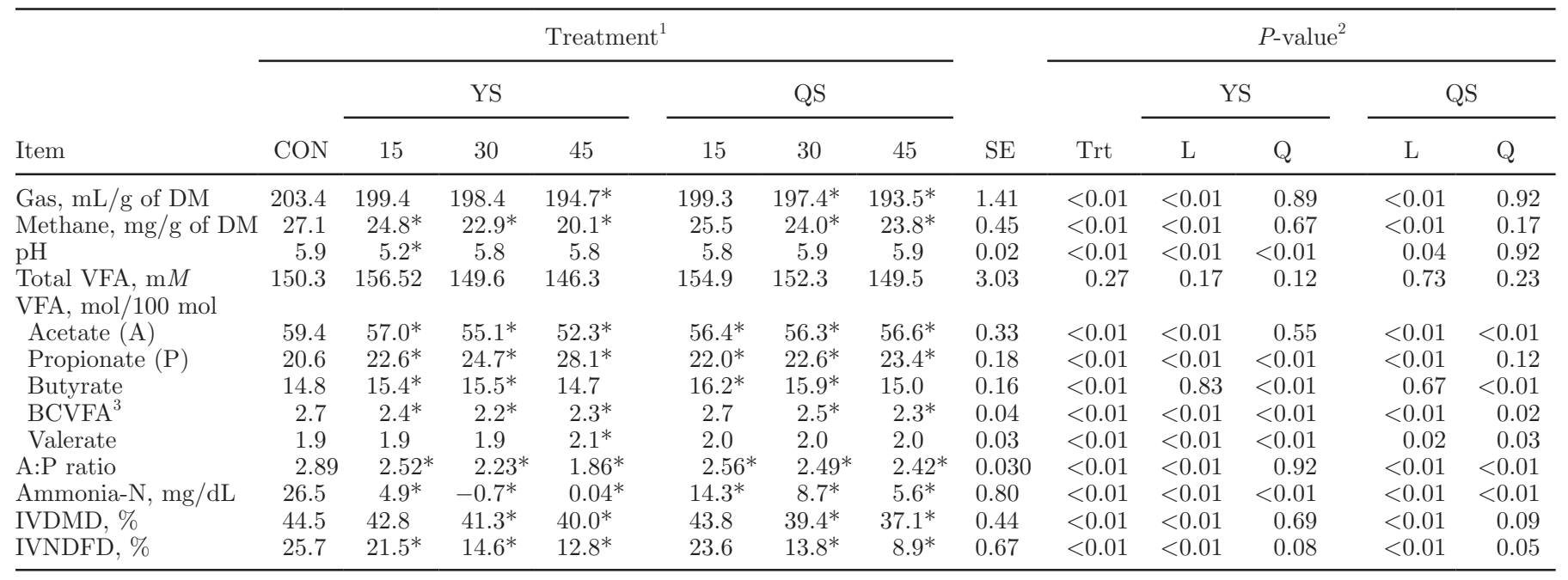

${ }^{1} \mathrm{CON}=$ no saponin additives; YS $=$ Y. schidigera (Desert King International, San Diego, CA); QS = Q. saponaria (Desert King International); both saponins were added at 15,30 , and $45 \mathrm{~g} / \mathrm{kg}$ of substrate DM.

${ }^{2} P$-values for Trt $=$ treatments; orthogonal contrasts for $\mathrm{L}=$ linear and $\mathrm{Q}=$ quadratic effects.

${ }^{3}$ Branched-chain volatile fatty acids (isobutyrate + isovalerate).

*Means within a row differ significantly from the CON $(P<0.05)$.

$\mathrm{g}$ of substrate and $20 \mathrm{~mL}$ of inoculum) was similar to the dose used in their study. Comparing results among studies remains a challenge because the dose level can be expressed on the basis of substrate addition (i.e., g/ $\mathrm{kg}$ of DM) or volume (i.e., g/L), and as actual saponin concentration or saponin source concentration. Also, the method for determining saponin concentration in the source product can differ (e.g., Wang et al., 1998: smilagenin equivalents; current study: butanol-extracted solubles).

The substantial contribution of protozoa to feed digestion in the rumen has been established in various studies as illustrated in a review by Veira (1986). The observed decrease in feed digestibility in our study may have resulted from a reduction in the number of protozoa as various studies have documented the antiprotozoal activity of saponins (Makkar et al., 1998; Wang et al., 1998; Lila et al., 2003). Valdez et al. (1986) observed in vitro that protozoal numbers decreased linearly from 36,000 to $29,000 / \mathrm{mL}$ as the concentration of saponin increased from 0 to $77 \mathrm{mg} / \mathrm{kg}$ of substrate. Although we did not measure protozoa directly, our observed decline in ammonia- $\mathrm{N}$ concentration is consistent with a reduction in protozoal numbers (Francis et al., 2002). Between 10 and $25 \%$ of methanogens are associated with ciliate protozoa (Stumm et al., 1982; Newbold et al., 1995), and eliminating ciliate protozoa from the rumen reduces methane emission by 30 to $45 \%$ (Jouany et al., 1981; Itabashi et al., 1984; Ushida et al., 1986). It is possible that the decline in methane production in our study was attributed to reduced protozoal numbers.

It is also possible that methane was lowered through an inhibition of the growth of $\mathrm{H}_{2}$-producing bacteria (Wallace et al., 1994; Wang et al., 1998) including cellulolytic bacteria and other bacteria that use pyruvateferredoxin oxidoreductase to metabolize pyruvate to acetyl-CoA (Wang et al., 2000). Reduction in cellulolytic bacteria is consistent with the observed reduction in IVNDFD.

Despite reductions in IVDMD, IVNDFD, and total gas and methane production, there were no effects on total VFA production. The reason for this inconsistency is not clear. Although total VFA production was not affected by saponin treatments, proportions of individual VFA were altered in a manner that was consistent with a reduction in IVNDFD and a shift in the flow of hydrogen toward more reduced fermentation end products. Proportion of propionate at all levels of saponin addition was greater $(P<0.01)$ than in the CON treatment and increased linearly $(P<0.01)$ with increasing level of saponin. Proportions of butyrate at the 2 lower levels of the saponin treatments (15 and 30 $\mathrm{g} / \mathrm{kg})$ were also greater $(P<0.01)$ than for the CON. Proportion of butyrate increased quadratically $(P<$ $0.01)$ with increasing level of YS and decreased quadratically $(P<0.01)$ with increasing level of QS. These results suggest that type and origin of saponin may influence the specific alteration in rumen fermentation 
that occurs. Pen et al. (2006) observed that both Y. schidigera and $Q$. saponaria extracts increased propionate concentration and decreased ammonia- $\mathrm{N}$ concentration and protozoal numbers, and that methane production was strongly inhibited by $Y$. schidigera but not by $Q$. saponaria extract. In contrast, in our study both YS and QS inhibited in vitro methane production despite the fact that the dose rates in the study by Pen et al. (2006) were considerably higher ( $Y$. schidigera: 0.210 , 0.421 , and $0.631 \mathrm{~g}$ of saponin/L; Q. saponaria: 0.138 , 0.276 , and $0.415 \mathrm{~g}$ of saponin/L) than the dose rates in our study ( $Y$. schidigera: $0.023,0.045$, and $0.068 \mathrm{~g}$ of saponin/L; Q. saponaria: $0.011,0.023$, and $0.034 \mathrm{~g}$ of saponin/L). The saponin sources in our study were powdered whole-plant $Y$. schidigera and Q. saponaria, whereas Pen et al. (2006) used liquid extract forms of these saponin sources. The whole-plant product contains polyphenolics, which may account for some of the activity, whereas the extract is low in this fraction (P. Cheeke; personal observation).

The negative effects of saponin supplementation on IVNDFD increased with increased dose rate, which suggests that lower levels of supplementation may attenuate the negative effects on fiber digestion. Furthermore, the IVDMD at the low $(15 \mathrm{~g} / \mathrm{kg}$ of substrate DM) level of the saponin treatments were not different $(P>0.05)$ from the CON treatment. However, IVDMD at the medium and high (30 and $45 \mathrm{~g} / \mathrm{kg}$ of substrate DM) levels of the saponin treatments were lower $(P<0.01)$ than the IVDMD of the CON treatment and decreased linearly $(P<0.01)$ with increasing level of saponin. Wang et al. (1998) found that Y. schidigera at $0.022 \mathrm{~g}$ of saponin/L altered proteolytic activity and reduced protozoal numbers, but did not affect DM digestibility, a result that is consistent with our results for the low level of saponin addition $(0.023 \mathrm{~g}$ of saponin/L).

The $\mathrm{pH}$ at the low $(15 \mathrm{~g} / \mathrm{kg}$ of substrate DM) level of the YS treatment was lower $(P<0.01)$ than that of the CON treatment. However, the $\mathrm{pH}$ at the medium and high (30 and $45 \mathrm{~g} / \mathrm{kg}$ of substrate DM) levels of the YS treatment and all levels of the QS treatment were not $(P>0.05)$ different from the CON treatment. In a recent in vitro study, Busquet et al. (2006) observed that $0.003 \mathrm{~g} / \mathrm{L}$ of $Y$. schidigera extract caused only a modest reduction in the $\mathrm{pH}$ of the medium from 5.9 to 5.8 , without altering total VFA or proportions of VFA during the incubation.

Although saponins from $Y$. schidigera and $Q$. saponaria lowered methane production in vitro, the reduction was associated with lower feed digestion. Also, both saponin sources lowered total gas production by the same proportion, but the effect of YS on ruminal fermentation generally appeared to be more pronounced than that of QS. This may be due in part to the higher concentration of saponin in YS compared with QS (6.0 vs. 3.0\%). Pen et al. (2006) reported variable effects on rumen fermentation between similar dose levels of $Y$. schidigera and $Q$. saponaria extracts in vitro, but as in our study, the saponin concentration in the $Y$. shidigera extract was slightly higher than that of the $Q$. saponaria extract (80 to 100 vs. 50 to $70 \mathrm{~g}$ of saponin $/ \mathrm{kg}$ of extract). Sen et al. (1998) indicated that the biological activity of saponin depends on its 3-dimensional spatial orientation, the structure of the lipophilic aglycon, as well as the sugar composition. A variety of triterpenoid saponin structures have been identified in $Q$. saponaria (Guo et al., 2000), and Y. schidigera consists of 8 different structures of spirostanol and furastonal glycosides (Oleszek et al., 2001). Although various chemical structures of saponins have been identified, it is not known how the structure may affect rumen fermentation.

\section{In Vivo Study}

The in vivo study was conducted to test the hypothesis that saponin from $Y$. schidigera or $Q$. saponaria would lower methane production without negatively affecting intake, digestibility, and milk production in dairy cows. The level of saponin product used in this study $(10 \mathrm{~g} / \mathrm{kg}$ of DM) was below the lowest dose (15 $\mathrm{g} / \mathrm{kg}$ of DM) used in the in vitro study to avoid potentially negative effects on nutrient digestion and animal performance. However, when expressed on the basis of rumen volume, the dose $(3.0 \mathrm{~g} / \mathrm{L})$ was actually higher than the lowest dose $(0.375 \mathrm{~g} / \mathrm{L})$ used in the in vitro study (in vivo dose calculated as follows: $10 \mathrm{~g} / \mathrm{kg}$ DM $\times 22.5 \mathrm{~kg} / \mathrm{d}(\mathrm{DMI}) \div 75 \mathrm{~L}$ (average rumen volume as measured by emptying rumen contents; data not presented).

Methane Production. Methane production expressed as grams per day or grams per kilogram of DMI did not differ $(P>0.05)$ among treatments (Table 3$)$. The DMI of the cows was not affected by treatment $(P$ $>0.05$ ) during the 3 -d chamber or 5 - $\mathrm{d} \mathrm{SF}_{6}$ measurement periods and averaged $21.7 \pm 0.71$ and $21.8 \pm 1.19 \mathrm{~kg} / \mathrm{d}$, respectively. Methane emission as measured by the $\mathrm{SF}_{6}$ technique was $13.7 \%$ lower than that measured in the environmental chambers. Higher $\mathrm{CH}_{4}$ emission values were expected for the chamber measurements because it also records $\mathrm{CH}_{4}$ released through the rectum, unlike the $\mathrm{SF}_{6}$ technique, which in our study only measured the respired and eructated emission of the animal. The magnitude of difference between the 2 techniques was, however, greater than the $4 \%$ reported by McGinn et al. (2006). The higher DMI in our study $(21.8 \mathrm{~kg} / \mathrm{d})$ compared with that $(6.9 \mathrm{~kg} / \mathrm{d})$ in the study by McGinn et al. (2006) may partially explain this discrepancy. An increase in DMI is often associated with an increase in 
Table 3. Dry matter intake and methane production for dairy cows fed a TMR supplemented with saponin from Yucca schidigera or Quillaja saponaria

\begin{tabular}{|c|c|c|c|c|c|c|c|}
\hline \multirow[b]{3}{*}{ Item $^{1}$} & \multirow{2}{*}{\multicolumn{3}{|c|}{ Treatment $^{2}$}} & \multirow[b]{3}{*}{$\mathrm{SE}$} & \multicolumn{3}{|c|}{$P$-value } \\
\hline & & & & & & \multicolumn{2}{|c|}{ Contrast $^{4}$} \\
\hline & $\mathrm{CON}$ & YS & QS & & $\operatorname{Trt}^{3}$ & 1 & 2 \\
\hline \multicolumn{8}{|l|}{ Chamber } \\
\hline DMI, kg/d & 21.8 & 22.0 & 21.2 & 0.71 & 0.67 & 0.81 & 0.40 \\
\hline $\mathrm{CH}_{4}, \mathrm{~g} / \mathrm{d}$ & 416.8 & 415.4 & 384.9 & 27.79 & 0.42 & 0.48 & 0.27 \\
\hline $\mathrm{CH}_{4}, \mathrm{~g} / \mathrm{kg}$ of DMI & 19.2 & 19.0 & 18.5 & 0.73 & 0.59 & 0.44 & 0.49 \\
\hline $\mathrm{CH}_{4}, \%$ of gross energy intake & 5.70 & 5.63 & 5.48 & 0.200 & 0.58 & 0.44 & 0.47 \\
\hline \multicolumn{8}{|l|}{$\mathrm{SF}_{6}$} \\
\hline DMI, kg/d & 21.8 & 21.5 & 22.1 & 1.19 & 0.48 & 0.97 & 0.24 \\
\hline $\mathrm{CH}_{4}, \mathrm{~g} / \mathrm{d}$ & 352.3 & 359.0 & 339.0 & 59.56 & 0.48 & 0.81 & 0.24 \\
\hline $\mathrm{CH}_{4}, \mathrm{~g} / \mathrm{kg}$ of $\mathrm{DMI}$ & 16.1 & 17.0 & 15.4 & 2.50 & 0.27 & 0.86 & 0.12 \\
\hline $\mathrm{CH}_{4}, \%$ of gross energy intake & 4.76 & 5.03 & 4.57 & 0.735 & 0.27 & 0.87 & 0.12 \\
\hline
\end{tabular}

${ }^{1}$ Chamber measurements determined with 12 animals over $3 \mathrm{~d}$ when animals were confined in environmental chambers; $\mathrm{SF}_{6}$ (sulfur hexafluoride) measurements determined with 6 animals over $5 \mathrm{~d}$ when animals were housed in individual tie stalls.

${ }^{2} \mathrm{CON}=$ no saponin additives; YS $=Y$. schidigera (Desert King International, San Diego, CA); QS $=Q . s a-$ ponaria (Desert King International). Y. schidigera and Q. saponaria were added at $10 \mathrm{~g} / \mathrm{kg}$ of DM.

${ }^{3}$ Trt $=$ treatment.

${ }^{4}$ Contrasts: $1=\mathrm{CON}$ vs. YS and QS; $2=\mathrm{YS}$ vs. QS

passage rate (Colucci et al., 1990), which could lead to greater postruminal digestion and hindgut fermentation and an increase in $\mathrm{CH}_{4}$ released via the rectum.

Several in vitro reports of reduced methane production in response to saponin supplementation exist (e.g., the present in vitro study; Hess et al., 2003a; Lila et al., 2003; Pen et al., 2006), but relatively few in vivo studies have reported on this effect. Among the in vivo studies there are reports of reduced (Hess et al., 2004; Santoso et al., 2004) and numerically reduced methane production (Pen et al., 2007), but also no effect on methane production (Sliwinski et al., 2002) as was observed in our study. The variability in response among studies may be due to differences in saponin source or dose level used.

Hess et al. (2004) used the dried fruits of S. saponaria and recorded a decrease in methane production, whereas Sliwinski et al. (2002) used a Y. schidigera extract and observed no effect on methane production. The difference in response between these 2 studies due to source is, however, confounded with dose level; 7.5 and $0.03 \mathrm{~g}$ of saponin $/ \mathrm{kg}$ of diet DM. The dose used by Santoso et al. (2004) was similar to the upper dose used by Sliwinski et al. (2002) when expressed on the basis of saponin-containing product concentration: 0.12 and $0.15 \mathrm{~g}$ of saponin source $/ \mathrm{kg}$ of diet DM, respectively. Although the source of saponin was $Y$. schidigera in both these studies, it was provided by different suppliers and the actual saponin content could have been different [saponin content of the extract was not given by Santoso et al. (2004)]. The dose rate used in the present study was almost 10-fold higher than that used in the study by Santoso et al. (2004) in which methane was decreased: 0.12 and $10 \mathrm{~g}$ of saponin source $/ \mathrm{kg}$ of diet DM, respectively. The saponin product used in these 2 studies were both from $Y$. schidigera and supplied by the same company (Desert King International), but the saponin content of different batches is needed to compare responses based on actual saponin dose levels. Thus, it is unclear whether the lack of an effect on methane production in our study relative to other in vivo studies was because of the source or dose level, or both, of the saponin product used and possibly the diet fed.

Total-Tract Digestibility of Nutrients. The apparent digestibility of DM did not differ among treatments and averaged $58.8 \pm 1.33 \%$ (Table 4). Similarly, the apparent digestibilities of gross energy, CP, NDF, and ADF were not affected $(P>0.05)$ by treatment in agreement with the results of Wu et al. (1994) who fed a powdered yucca extract product (Deodorase supplied by Alltech, Nicholasville, KY; containing 30\% Y. schidigera extract and $70 \%$ inactive carriers) at 0 or 4 $\mathrm{g} / \mathrm{d}$ and observed no difference in ruminal digestibility of $\mathrm{OM}$ and ADF. The intake of digestible DM $(\mathrm{kg} / \mathrm{d})$ and digestible energy (Mcal/d) were similar among treatments despite the lower DMI for cows on the CON treatment. Hristov et al. (1999) intraruminally dosed 0 (control), 20, or $60 \mathrm{~g} / \mathrm{d}$ of powdered $Y$. schidigera in heifers fed a $61 \%$ barley grain and $39 \%$ alfalfa silage diet (DM basis) and found that the rate and extent of in situ DM digestibility and apparent digestibility of 
Table 4. Nutrient digestibility and intake of digestible DM and energy of dairy cows fed a TMR supplemented with saponin from Yucca schidigera or Quillaja saponaria

\begin{tabular}{|c|c|c|c|c|c|c|c|}
\hline \multirow[b]{3}{*}{ Item } & & & & \multirow[b]{3}{*}{$\mathrm{SE}$} & \multicolumn{3}{|c|}{$P$-value } \\
\hline & \multicolumn{3}{|c|}{ Treatment $^{1}$} & & \multirow[b]{2}{*}{$\operatorname{Trt}^{2}$} & \multicolumn{2}{|c|}{ Contrast $^{3}$} \\
\hline & $\mathrm{CON}$ & YS & QS & & & 1 & 2 \\
\hline \multicolumn{8}{|l|}{ Digestibility, \% } \\
\hline DM & 59.3 & 58.5 & 58.5 & 1.33 & 0.88 & 0.62 & 0.98 \\
\hline Gross energy & 59.9 & 59.4 & 59.5 & 1.34 & 0.96 & 0.79 & 0.96 \\
\hline $\mathrm{CP}$ & 58.7 & 58.4 & 57.0 & 1.51 & 0.63 & 0.54 & 0.44 \\
\hline $\mathrm{NDF}$ & 39.8 & 37.4 & 36.1 & 2.29 & 0.49 & 0.25 & 0.69 \\
\hline $\mathrm{ADF}$ & 37.6 & 34.4 & 32.4 & 2.57 & 0.27 & 0.13 & 0.51 \\
\hline \multicolumn{8}{|l|}{ Intake } \\
\hline Digestible DM, kg/d & 13.4 & 13.7 & 13.3 & 0.64 & 0.69 & 0.78 & 0.44 \\
\hline Digestible energy, Mcal/d & 60.5 & 61.9 & 59.9 & 2.94 & 0.72 & 0.86 & 0.45 \\
\hline
\end{tabular}

DM, NDF, and CP were not affected by treatments. However, some authors reported a decrease in ruminal fiber digestion ( $\mathrm{Lu}$ and Jorgensen, 1987; Hess et al., 2003a). Despite a decrease in ruminal fiber digestion, $\mathrm{Lu}$ and Jorgensen (1987) reported an increase in totaltract digestibility as a result of a marked increased in small intestine digestibility.

Therefore, the lack of a decrease in fiber digestion in our in vivo study may be a result of the lower dose level as compared with the accompanying in vitro study in which a decrease in IVNDFD was recorded. Alternatively, digestion in the small intestine was increased resulting in no difference in total-tract digestibility. However, ruminal fermentation was not affected by saponins (see results below), suggesting that ruminal fiber digestion was not impaired.

The effect of saponin extracts on methane production is sometimes, but not always, explained by a decrease in fiber digestibility. Among studies that recorded a decrease in methane production, Hess et al. (2004) reported a decrease in apparent total-tract NDF and ADF digestibility with supplements of $S$. saponaria, Santoso et al. (2004) reported no effect on NDF and ADF digestibility with $Y$. schidigera, and Pen et al. (2007) reported an increase in NDF digestibility with Q. saponaria. The lack of an effect on methane production in our study is consistent with the lack of effect on NDF digestibility.

\section{Ruminal Fermentation}

The saponins had no effect on ruminal fermentation when averaged over the various sampling times during the periods (Table 5), suggesting that the saponins did not alter diet fermentability or energy availability. Supplementation with YS is reported to decrease rumen $\mathrm{pH}$ (Wu et al., 1994) or have no effect (Hussain and Cheeke, 1995). Hristov et al. (1999) observed a slightly decreased (not significant) ruminal $\mathrm{pH}$ in heifers receiving from 20 to $60 \mathrm{~g} / \mathrm{d}$ of a powdered (wholeplant) saponin source (4.4\% saponin). Klita et al. (1996) suggested that reduction of protozoa due to the addition of saponin was mediated by a reduction in ruminal $\mathrm{pH}$. In our study, the saponins had no effect on ruminal $\mathrm{pH}$ (averaged $5.92 \pm 0.131$ ) or the protozoal population, which was composed predominantly (96\%) of Entodinium spp. This is in agreement with Eryavuz and Dehority (2004) who observed that feeding up to $20 \mathrm{~g} / \mathrm{d}(\mathrm{DMI}=1.09 \mathrm{~kg} /$ head per day) of $Y$. schidigera extracts (4.4\% saponin) to sheep for a period of $3 \mathrm{wk}$ did not affect ruminal protozoal numbers.

Unlike in the study by Sliwinski et al. (2002) where feeding saponins reduced ruminal ammonia-N concentration, treatments in our study had no effect on ammonia- $\mathrm{N}$ concentration. This is consistent with the results of Wu et al. (1994) who administered up to $8 \mathrm{~g} / \mathrm{d}$ of $Y$. schidigera extract via ruminal cannula to cows fed an alfalfa hay TMR and observed that the treatments did not affect ruminal ammonia- $\mathrm{N}$ concentration, $\mathrm{pH}$, or VFA concentration.

It is possible that the lack of response in rumen fermentation variables, and consequently methane production, may be due to an adaptation effect of the rumen microorganisms (Newbold et al., 1997; Teferedegne et al., 1999). Newbold et al. (1997) reported a decrease in protozoal numbers after $4 \mathrm{~d}$ of feeding saponins (Sesbania sesban) to sheep, but the population recovered after another $10 \mathrm{~d}$. In our study, there was a tendency for a 


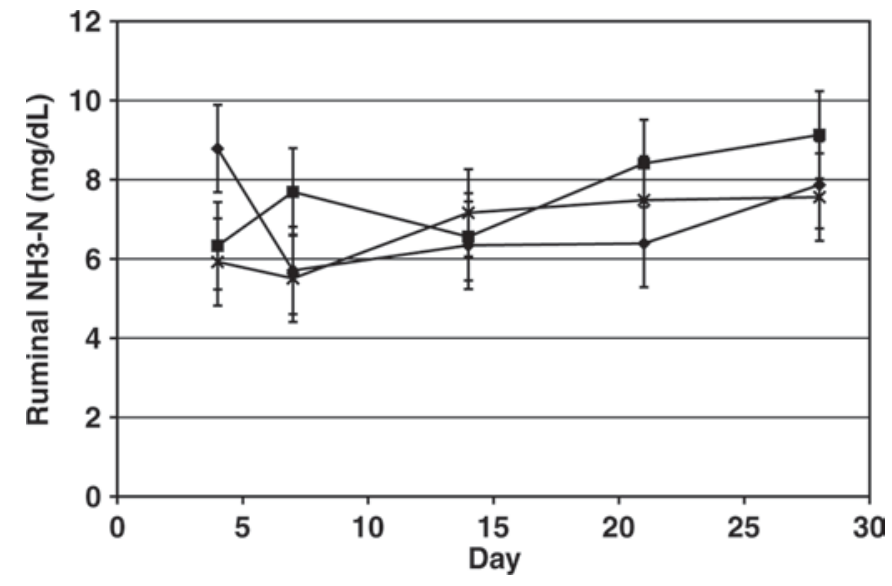

Figure 1. Ruminal ammonia-N in dairy cows fed a barley silagebased lactation TMR without supplementation ( $\mathbf{\square}$; control), or supplemented with saponin from Yucca schidigera $(\bullet)$ or Quillaja saponaria $(\times)$ at $10 \mathrm{~g} / \mathrm{kg}$ of DM. Values are least squares means and error bars represent standard errors of the means.

treatment $\times$ day interaction $(P=0.06)$ for ruminal ammonia- $\mathrm{N}$ concentration. An initial numerical decrease in ammonia- $\mathrm{N}$ concentration occurred for YS and QS, but the effect dissipated later (Figure 1), indicating a potential adaptation of ruminal microorganisms to the effect of saponins. No treatment $\times$ day interaction $(P$
$>0.05)$ was recorded for any other rumen fermentation measurements, however.

A major source of ruminal ammonia- $\mathrm{N}$ concentration is proteolysis of bacterial protein, occurring as a result of ingestion of ruminal bacteria by protozoa. In studies where feeding saponins has resulted in a reduction of ruminal ammonia- $\mathrm{N}$ concentration, the reduction was attributed to the antiprotozoal activity of saponins (Makkar et al., 1998; Lila et al., 2003). These compounds are thought to form irreversible complexes with cholesterol in the protozoal cell membrane, leading to cell lysis (Cheeke, 2000; Francis et al., 2002). The lack of treatment effects on ammonia-N concentration in our results is therefore consistent with no effect on ruminal protozoal numbers.

The effects of saponins on VFA profile have been inconsistent among studies. Hristov et al. (1999) reported an increase in propionate concentration and a decrease in butyrate concentration and acetate:proprionate ratio with intraruminal supplementation of $Y$. schidigera to beef heifers. Similarly to our in vivo findings, however, others (Valdez et al., 1986; Wu et al., 1994; Klita et al., 1996) observed no changes in VFA profiles. This inconsistency might be explained by the differences in saponin sources and concentration, or the forage to concentrate ratio of the diet. Increases in propionate

Table 5. Ruminal fermentation, $\mathrm{pH}$, and protozoal numbers in ruminal fluid from dairy cows fed a TMR supplemented with saponin from Yucca schidigera or Quillaja saponaria

\begin{tabular}{|c|c|c|c|c|c|c|c|}
\hline \multirow[b]{3}{*}{ Item $^{2}$} & \multirow{2}{*}{\multicolumn{3}{|c|}{ Treatment $^{1}$}} & \multirow[b]{3}{*}{$\mathrm{SE}$} & \multicolumn{3}{|c|}{$P$-value } \\
\hline & & & & & \multirow[b]{2}{*}{$\operatorname{Trt}^{3}$} & \multicolumn{2}{|c|}{ Contrast $^{4}$} \\
\hline & $\mathrm{CON}$ & YS & QS & & & 1 & 2 \\
\hline $\mathrm{pH}$ & 5.92 & 5.91 & 5.94 & 0.131 & 0.89 & 0.93 & 0.67 \\
\hline Total VFA, mM & 128.4 & 127.3 & 128.8 & 3.39 & 0.85 & 0.89 & 0.60 \\
\hline \multicolumn{8}{|l|}{ VFA, mol/100 mol } \\
\hline Acetate (A) & 61.5 & 61.7 & 61.6 & 1.27 & 0.92 & 0.72 & 0.85 \\
\hline Propionate $(\mathrm{P})$ & 23.1 & 22.9 & 22.8 & 1.62 & 0.92 & 0.69 & 0.96 \\
\hline Butyrate & 11.4 & 11.5 & 11.5 & 0.56 & 0.94 & 0.73 & 0.99 \\
\hline Valerate & 1.49 & 1.45 & 1.50 & 0.044 & 0.26 & 0.72 & 0.12 \\
\hline Isobutyrate & 0.71 & 0.70 & 0.71 & 0.023 & 0.95 & 0.84 & 0.82 \\
\hline Isovalerate & 1.44 & 1.44 & 1.48 & 0.079 & 0.80 & 0.69 & 0.61 \\
\hline A:P ratio & 2.80 & 2.80 & 2.81 & 0.240 & 0.98 & 0.86 & 0.95 \\
\hline Ammonia-N, mg/dL & 7.62 & 6.73 & 7.02 & 0.867 & 0.09 & 0.04 & 0.44 \\
\hline \multicolumn{8}{|l|}{ Protozoa, $\times 10^{5} / \mathrm{mL}$} \\
\hline Holotrichs ${ }^{5}$ & 0.213 & 0.202 & 0.197 & 0.080 & 0.90 & 0.67 & 0.88 \\
\hline Entodiniomorphs ${ }^{6}$ & 5.90 & 5.92 & 5.90 & 0.083 & 0.99 & 0.97 & 0.94 \\
\hline Total & 6.15 & 6.17 & 6.13 & 0.079 & 0.99 & 0.99 & 0.91 \\
\hline \multicolumn{8}{|c|}{$\begin{array}{l}{ }^{1} \mathrm{CON}=\text { no saponin additives; YS }=Y . \text { schidigera } \text { (Desert King International, San Diego, CA); QS }=Q . s a- \\
\text { ponaria (Desert King International). } Y . \text { schidigera and } Q . \text { saponaria were added at } 10 \mathrm{~g} / \mathrm{kg} \text { of DM. }\end{array}$} \\
\hline \multicolumn{8}{|c|}{$\begin{array}{l}{ }^{2} \text { Values are least squares means averaged over sampling days }(\mathrm{d} 4,7,14,21 \text {, and } 28) \text {; no treatment by day } \\
\text { interactions were observed }(P>0.05) \text {. }\end{array}$} \\
\hline \multicolumn{8}{|c|}{${ }^{3}$ Trt $=$ treatment. } \\
\hline \multicolumn{8}{|c|}{${ }^{4}$ Contrasts: $1=$ CON vs. YS and QS, $2=$ YS vs. QS. } \\
\hline${ }^{5}$ Holotrichs $=$ Isotricha & ytricha. & & & & & & \\
\hline $\begin{array}{l}{ }^{6} \text { Entodiniomorphs }= \\
\text { Ophryoscolex. }\end{array}$ & ium + & plodiniu & + Poly & on + & dint & + & nium + \\
\hline
\end{tabular}


Table 6. Dry matter intake, milk yield and composition, BW and BW changes of dairy cows fed a TMR supplemented with saponin from Yucca schidigera or Quillaja saponaria

\begin{tabular}{|c|c|c|c|c|c|c|c|}
\hline \multirow[b]{3}{*}{ Item } & & & & \multirow[b]{3}{*}{$\mathrm{SE}$} & \multicolumn{3}{|c|}{$P$-value } \\
\hline & \multicolumn{3}{|c|}{ Treatment $^{1}$} & & \multirow[b]{2}{*}{$\operatorname{Trt}^{2}$} & \multicolumn{2}{|c|}{ Contrast $^{3}$} \\
\hline & $\mathrm{CON}$ & YS & QS & & & 1 & 2 \\
\hline DMI, $\mathrm{kg} / \mathrm{d}$ & 21.9 & 23.1 & 22.5 & 0.70 & $<0.01$ & $<0.01$ & 0.06 \\
\hline Milk yield, kg/d & 30.5 & 31.0 & 30.3 & 1.12 & 0.34 & 0.59 & 0.17 \\
\hline \multicolumn{8}{|l|}{ Milk fat } \\
\hline$\%$ & 3.56 & 3.53 & 3.50 & 0.108 & 0.65 & 0.45 & 0.60 \\
\hline $\mathrm{kg} / \mathrm{d}$ & 1.10 & 1.10 & 1.07 & 0.042 & 0.58 & 0.57 & 0.39 \\
\hline \multicolumn{8}{|l|}{ Milk protein } \\
\hline$\%$ & 3.26 & 3.23 & 3.21 & 0.070 & 0.18 & 0.09 & 0.48 \\
\hline $\mathrm{kg} / \mathrm{d}$ & 1.02 & 1.02 & 0.98 & 0.035 & 0.10 & 0.27 & 0.06 \\
\hline \multicolumn{8}{|l|}{ Milk lactose } \\
\hline$\%$ & 4.64 & 4.66 & 4.64 & 0.051 & 0.22 & 0.45 & 0.12 \\
\hline $\mathrm{kg} / \mathrm{d}$ & 1.44 & 1.45 & 1.42 & 0.056 & 0.52 & 0.86 & 0.26 \\
\hline Milk efficiency, ${ }^{4} \mathrm{~kg} / \mathrm{kg}$ & 1.41 & 1.36 & 1.36 & 0.049 & 0.02 & $<0.01$ & 0.88 \\
\hline $\mathrm{SCC}, \times 10^{3} / \mathrm{mL}$ & 505.1 & 231.1 & 319.5 & 177.2 & 0.08 & 0.04 & 0.46 \\
\hline \multicolumn{8}{|l|}{ BW } \\
\hline Initial, $\mathrm{kg}$ & 626.5 & 629.6 & 625.8 & 16.21 & 0.35 & 0.62 & 0.17 \\
\hline Final, kg & 642.1 & 640.8 & 639.3 & 15.27 & 0.53 & 0.34 & 0.56 \\
\hline Change, kg & 15.6 & 11.2 & 13.6 & 5.40 & 0.44 & 0.29 & 0.49 \\
\hline $\mathrm{ADG}, \mathrm{kg} / \mathrm{d}$ & 0.56 & 0.40 & 0.48 & 0.193 & 0.44 & 0.29 & 0.49 \\
\hline
\end{tabular}

concentration as a result of inclusion of saponins are more pronounced for a high-grain diet (Hristov et al., 1999) than for high-forage diets (Hess et al., 2003a,b), possibly because of differences in rumen $\mathrm{pH}$. Cardozo et al. (2005) evaluated the effects of 5 doses $(0,0.3,3$, 30 , and $300 \mathrm{mg} / \mathrm{L}$ ) of $Y$. schidigera ( $8 \%$ sarsaponin) on in vitro rumen microbial fermentation at $\mathrm{pH} 5.5$ and 7.0 and observed that at $\mathrm{pH} 5.5, Y$. schidigera increased the proportion of propionate, but not at $\mathrm{pH}$ 7.0.

$B W$ Changes, DMI, Milk Yield, and Milk Composition. There were no differences in final BW or BW changes (Table 6). The DMI of cows fed YS or QS was greater than for $\mathrm{CON}$ cows and tended $(P=$ $0.10)$ to be higher for cows fed YS than for cows fed QS. There were no effects of saponin supplementation on milk yield or milk component yields and concentration. Because of the higher DMI of cows fed saponins, milk production efficiency measured as milk production per unit of DMI was lower $(P<0.05)$ for the saponin treatments (1.41 vs. $1.37 \pm 0.04 \mathrm{~kg} / \mathrm{kg}$, control vs. saponins, respectively). Saponin supplementation decreased somatic cell count compared with CON cows.

The lower milk production efficiency observed for cows fed saponin was apparently not related to the effects of saponins on nutrient digestion, given the lack of effect of saponins on ruminal fermentation and totaltract nutrient digestion. However, it is possible that saponins reduced intestinal absorption of nutrients. Saponins from gypsophila, quillaja, clover, guar, and alfalfa can lower transmural potential difference across the small intestine in rats (Gee et al., 1989). Transmural potential difference is the electrochemical gradient that acts as a driving force for active nutrient transport across the brush border membrane of the intestine.

In conclusion, in vitro experiments show a reduction in protozoal activity with saponin treatment (Wallace et al., 1994; Wang et al., 1998; Lila et al., 2003); however, this reduction in protozoal activity is not always observed in vivo, as was the case in our results. Differences between in vitro and in vivo results can be due to differences in the basal diet, the dosage of saponins used, and the potential adaptation of the rumen microflora in in vivo studies (Lu and Jorgensen, 1987). Saponins are degraded by saliva after prolonged feeding of saponin-rich feeds (Odenyo et al., 1997; Teferedegne, 2000). Odenyo et al. (1997) found that the positive effects of saponins were more pronounced when they were administered directly into the rumen rather than added to the feed. Additionally, previous long-term in vitro studies (Wang et al., 1998; Cardozo et al., 2004) demonstrated that the effects of some plant extracts on rumen microbial fermentation might be transient rather than permanent. Further research is warranted to explain the discrepancies between in vitro and in 
vivo responses and to establish the efficacy of various sources of saponin in animal feeding studies.

\section{ACKNOWLEDGMENTS}

The authors thank Agriculture and Agri-Food Canada staff, including K. Andrews (animal care and sampling), T. Coates (gas measurements), B. Farr (laboratory analysis), W. Smart (laboratory analysis), A. Furtado (laboratory analysis), and D. Vedres (chromatography). This study was funded by Agriculture and Agri-Food Canada's Matching Investment Initiative and Dairy Farmers of Canada.

\section{REFERENCES}

AOAC. 1995. Official Methods of Analysis. 16th ed. Association of Official Analytical Chemists. Arlington, VA.

Benchaar, C., Y. Wang, A. V. Chaves, T. A. McAllister, and K. A. Beauchemin. 2007. Use of plant extracts in ruminant nutrition. Pages 465-489 in Advances in Medicinal Plant Research. S. N Acharya and J. E. Thomas, ed. Research Signpost, Kerala, India.

Busquet, M., S. Calsamiglia, A. Ferret, and C. Kamel. 2006. Plant extracts affect in vitro rumen microbial fermentation. J. Dairy Sci. 89:761-771.

Canadian Council on Animal Care. 1993. Guide to the Care and Use of Experimental Animals. Volume 1. 2nd ed. E. D. Olfert, B. M. Cross, and A. A. McWilliam, ed. CCAC, Ottawa, Ontario, Canada.

Cardozo, P. W., S. Calsamiglia, A. Ferret, and C. Kamel. 2004. Effects of natural plant extracts on ruminal protein degradation and fermentation profiles in continuous culture. J. Anim. Sci. $82: 3230-3236$

Cardozo, P. W., S. Calsamiglia, A. Ferret, and C. Kamel. 2005. Screening for the effects of natural plant extracts at two $\mathrm{pH}$ levels on in vitro rumen microbial fermentation of a high-concentrate diet for beef cattle. J. Anim. Sci. 83:2572-2579.

Cheeke, P. R. 2000. Actual and potential applications of Yucca schidigera and Quillaja saponaria saponins in human and animal nutrition. J. Anim. Sci. 77:1-10.

Colucci, P. E., G. K. Macleod, W. L. Grovum, I. McMillan, and D. J. Barney. 1990. Digesta kinetics in sheep and cattle fed diets with different forage to concentrate ratios at high and low intakes. J. Dairy Sci. 73:2143-2156.

Eryavuz, A., and B. A. Dehority. 2004. Effect of Yucca schidigera extract on the concentration of rumen microorganisms in sheep. Anim. Feed Sci. Technol. 117:215-222.

Fedorak, P. M., and S. E. Hrudey. 1983. A simple apparatus for measuring gas production by methanogenic cultures in serum bottles. Environ. Technol. Lett. 4:425-432.

Francis, G., Z. Kerem, H. P. S. Makkar, and K. Becker. 2002. The biological action of saponins in animal systems: Reviews. Br. J. Nutr. 88:587-605.

Gee, J. M., K. R. Price, C. L. Ridout, I. T. Johnson, and G. R. Fenwick. 1989. Effects of some purified saponins on transmural potential difference in mammalian small intestine. Toxicol. In Vitro 3:85-90.

Guo, S., E. Falk, L. Kenne, B. Rönnberg, and B. G. Sundquist. 2000. Triterpenoid saponin-containing an acetylated branched D-fucosyl residue from Quillaja saponario Molina. Phytochemistry 53:861868.

Hess, H. D., R. A. Beuret, M. Lotscher, I. K. Hindrichsen, A. Machmuller, J. E. Carulla, C. E. Lascano, and M. Kreuzer. 2004. Ruminal fermentation, methanogenesis and nitrogen utilization of sheep receiving tropical grass hay-concentrate diets offered with
Sapindus saponaria fruits and Cratylia argentea foliage. Anim. Sci. 79:177-189.

Hess, H. D., M. Kreuzer, T. E. Diaz, C. E. Lascano, J. E. Carulla, C. R. Soliva, and A. Machmuller. 2003a. Saponin rich tropical fruits affect fermentation and methanogenesis in faunated and defaunated rumen fluid. Anim. Feed Sci. Technol. 109:79-94.

Hess, H. D., L. M. Monsalve, C. E. Lascano, J. E. Carulla, T. E. Diaz, and M. Kreuzer. 2003b. Supplementation of a tropical grass diet with forage legumes and Sapindus saponaria fruits: Effects on in vitro ruminal nitrogen turnover and methanogenesis. Aust. J. Agric. Res. 54:703-713.

Hristov, A. N., T. A. McAllister, F. H. Van Herk, K. J. Cheng, C. J. Newbold, and P. R. Cheeke. 1999. Effect of Yucca schidigera on ruminal fermentation and nutrient digestion in heifers. J. Anim. Sci. 77:2554-2563.

Hussain, I., and P. R. Cheeke. 1995. Effect of dietary Yucca schidigera extract on rumen and blood profiles of steers fed concentrate- or roughage-based diets. Anim. Feed Sci. Technol. 51:231-242.

Intergovernmental Panel on Climate Change. 2007. Climate change 2007: Synthesis Report. http://www.ipcc.ch/pdf/assessmentreport/ar4/syr/ar4_syr.pdf Accessed July 8, 2008.

Itabashi, H., T. Kobayashi, and M. Matsumoto. 1984. The effects of rumen ciliate protozoa on energy metabolism and some constituents in rumen fluid and blood plasma of goats. Jpn. J. Zootech. Sci. $55: 248-255$.

Johnson, K. A., and D. E. Johnson. 1995. Methane emissions from cattle. J. Anim. Sci. 73:2483-2492.

Jouany, J. P., B. Zainab, J. Senaud, C. A. Groliere, J. Grain, and P. Trivend. 1981. Role of the rumen ciliate protozoa Polyplastron multivesiculatum, Entodinium spp. and Isotricha prostoma in the digestion of a mixed diet in sheep. Reprod. Nutr. Dev. 21:871884.

Klita, P. T., G. W. Mathison, T. W. Fenton, and R. T. Hardin. 1996. Effect of alfalfa root saponins on digestive function in sheep. J. Anim. Sci. 74:1144-1156.

Lila, Z. A., N. Mohammed, S. Kanda, T. Kamada, and H. Itabashi. 2003. Effect of sarsaponin on ruminal fermentation with particular reference to methane production in vitro. J. Dairy Sci. 86:33303336

Lu, C. D., and N. A. Jorgensen. 1987. Alfalfa saponins affect site and extent of nutrient digestion in ruminants. J. Nutr. 117:919-927.

Makkar, H. P. S., S. Sen, M. Blummel, and K. Becker. 1998. Effect of fractions containing saponins from Yucca schidigera, Quillaja saponaria and Acacia auriculoformis on rumen fermentation. J. Agric. Food Chem. 46:4324-4328.

McGinn, S. M., K. A. Beauchemin, T. Coates, and D. Colombatto. 2004. Methane emissions from beef cattle: Effects of monensin, sunflower oil, enzymes, yeast, and fumaric acid. J. Anim. Sci. 82:3346-3356.

McGinn, S. M., K. A. Beauchemin, A. D. Iwaasa, and T. A. McAllister. 2006. Assessment of the sulfur hexafluoride $\left(\mathrm{SF}_{6}\right)$ tracer technique for measuring enteric methane emission from cattle. J. Environ. Qual. 35:1686-1691.

Menke, K. H., L. Raab, A. Salewski, H. Steingass, D. Fritz, and W. Schneider. 1979. The estimation of the digestibility and metabolizable energy content of ruminant feedingstuffs from the gas production when they are incubated with rumen liquor in vitro. J. Agric.Sci. (Camb.) 93:217-222.

Newbold, C. J., S. M. El Hassan, J. Wang, M. E. Ortega, and R. J. Wallace. 1997. Influence of foliage from African multipurpose trees on activity of rumen protozoa and bacteria. Br. J. Nutr. $78: 237-249$

Newbold, C. J., B. Lassalas, and J. P. Jouany. 1995. The importance of methanogens associated with ciliate protozoa in ruminal methane production in vitro. Lett. Appl. Microbiol. 21:230-234.

NRC. 2001. Nutrient Requirements of Dairy Cattle. 7th rev. ed National Academy Press, Washington, DC

Odenyo, A. A., P. O. Osuji, and O. Karanfil. 1997. Effects of multipurpose tree (MPT) supplements on ruminant ciliate protozoa. Anim. Feed Sci. Technol. 67:169-180. 
Ogimoto, K., and S. Imai. 1981. Atlas of Rumen Microbiology. Japan Sci. Soc. Press, Tokyo, Japan.

Oleszek, W., M. Sitek, A. Stochmal, S. Piacente, C. Pizza, and P. Cheeke. 2001. Steroidal saponins of Yucca schidigera Roeszl. J. Agric. Food Chem. 49:4392-4396.

Pen, B., C. Sar, B. Mwenya, K. Kuwaki, R. Morikawa, and J. Takahashi. 2006. Effects of Yucca schidigera and Quillaja saponaria extracts on in vitro ruminal fermentation and methane emission. Anim. Feed Sci. Technol. 129:175-186.

Pen, B., K. Takaura, S. Yamaguchi, R. Asa, and J. Takahashi. 2007. Effects of Yucca shidigera and Quillaja saponaria with or without $\beta$ 1-4 galacto-oligosaccharides on ruminal fermentation, methane production and nitrogen utilization in sheep. Anim. Feed Sci. Technol. 138:75-88.

Santoso, B., B. Mwenya, C. Sar, Y. Gamo, T. Kobayashi, R. Morikawa, K. Kimura, H. Mizukoshi, and J. Takahashi. 2004. Effects of supplementing galacto-oligosaccharides, Yucca schidigera or nisin on rumen methanogenesis, nitrogen and energy metabolism in sheep. Livest. Prod. Sci. 91:209-217.

SAS Institute. 2001. System for Windows Release 9.1. SAS Inst. Inc., Cary, NC.

Sen, S., H. P. S. Makkar, and K. Becker. 1998. Alfalfa saponins and their implication in animal nutrition. J. Agric. Food Chem. 46:131-140.

Sliwinski, B. J., M. Kreuzer, H. R. Wettstein, and A. Machmuller. 2002. Rumen fermentation and nitrogen balance of lambs fed diets containing plant extracts rich in tannins and saponins, and associated emissions of nitrogen and methane. Arch. Anim. Nutr. 56:379-392.

Stumm, C. K., H. J. Gijzen, and G. D. Vogels. 1982. Association of methanogenic bacteria with ovine rumen ciliates. Br. J. Nutr. 47:95-99.

Teferedegne, B. 2000. New perspectives on the use of tropical plants to improve ruminant nutrition. Proc. Nutr. Soc. 59:209-214.
Teferedegne, B., F. McIntosh, P. O. Osuji, A. A. Odenyo, R. J. Wallace, and C. J. Newbold. 1999. Influence of foliage from different accessions of the subtropical leguminous tree, Sesbania sesban on rumen protozoa in Ethiopian and Scottish sheep. Anim. Feed Sci. Technol. 78:11-20.

Ushida, K., A. Miyazaki, and R. Kawashima. 1986. Effect of defaunation on ruminal gas and VFA production in vitro. Jpn. J. Zootech. Sci. 57:71-77.

Valdez, F. R., L. J. Bush, A. L. Goetsch, and F. N. Owens. 1986. Effect of steroidal sapogenins on ruminal fermentation and on production of lactating dairy cows. J. Dairy Sci. 69:1568-1575.

Van Soest, P. J., J. B. Robertson, and B. A. Lewis. 1991. Methods for dietary fiber, neutral detergent fiber, and nonstarch polysaccharides in relation to animal nutrition. J. Dairy Sci. 74:3583-3597.

Veira, D. M. 1986. The role of ciliate protozoa in nutrition of the ruminant. J. Anim. Sci. 63:1547-1560.

Wallace, R. J., L. Arthaud, and C. J. Newbold. 1994. Influence of Yucca shidigera extract on ruminal ammonia concentrations and ruminal microorganisms. Appl. Environ. Microbiol. 60:1762-1767.

Wang, Y., T. A. McAllister, C. J. Newbold, L. M. Rode, P. R. Cheeke, and K. J. Cheng. 1998. Effects of Yucca schidigera extract on fermentation and degradation of steroidal saponins in the rumen simulation technique (RUSITEC). Anim. Feed Sci. Technol. 74:143-153.

Wang, Y., T. A. McAllister, L. J. Yanke, and P. R. Cheeke. 2000. Effect of steroidal saponin from Yucca schidigera extract on ruminal microbes. J. Appl. Microbiol. 88:887-896.

Weatherburn, M. W. 1967. Phenol-hypochlorite reaction for determination of ammonia. Anal. Chem. 39:971-974.

Wu, Z., M. Sadik, F. T. Sleiman, J. M. Simas, M. Pessarakli, and J. T. Huber. 1994. Influence of yucca extract on ruminal metabolism in cows. J. Anim. Sci. 72:1038-1042. 